IZA DP No. 4193

Antagonistic Managers, Careless Workers and Extraverted Salespeople: An Examination of Personality in Occupational Choice

Roger Ham

P.N. (Raja) Junankar

Robert Wells

May 2009 


\title{
Antagonistic Managers, Careless Workers and Extraverted Salespeople: An Examination of Personality in Occupational Choice
}

\author{
Roger Ham \\ University of Western Sydney \\ P.N. (Raja) Junankar \\ University of Western Sydney \\ and IZA \\ Robert Wells \\ University of Western Sydney
}

Discussion Paper No. 4193

May 2009

IZA

P.O. Box 7240

53072 Bonn

Germany

\author{
Phone: +49-228-3894-0 \\ Fax: +49-228-3894-180 \\ E-mail: iza@iza.org
}

\begin{abstract}
Any opinions expressed here are those of the author(s) and not those of IZA. Research published in this series may include views on policy, but the institute itself takes no institutional policy positions.

The Institute for the Study of Labor (IZA) in Bonn is a local and virtual international research center and a place of communication between science, politics and business. IZA is an independent nonprofit organization supported by Deutsche Post Foundation. The center is associated with the University of Bonn and offers a stimulating research environment through its international network, workshops and conferences, data service, project support, research visits and doctoral program. IZA engages in (i) original and internationally competitive research in all fields of labor economics, (ii) development of policy concepts, and (iii) dissemination of research results and concepts to the interested public.
\end{abstract}

IZA Discussion Papers often represent preliminary work and are circulated to encourage discussion. Citation of such a paper should account for its provisional character. A revised version may be available directly from the author. 


\begin{abstract}
Antagonistic Managers, Careless Workers and Extraverted Salespeople: An Examination of Personality in Occupational Choice

This paper is an econometric investigation of the choice of individuals between a number of occupation groupings utilising an extensive array of conditioning variables measuring a variety of aspects of individual heterogeneity. Whilst the model contains the main theory of occupational choice, human capital theory, it also tests dynasty hysteresis through parental status variables. The focus is an examination of the relationship between choice and personality with the inclusion of psychometrically derived personality variables. Occupational choice is modelled using multinomial logit estimation using the Household Income and Labour Dynamics in Australia (HILDA) survey data. Human capital variables are found to exhibit strong credentialism effects. Parental status has a small and limited effect on occupation outcomes indicative of only some small dynasty hysteresis. On the other hand, personality effects are found to be significant, relatively large and persistent across all occupations. Further, the strength of these personality effects are such that they can in many instances rival that of various education credentials. These personality effects include but are not limited to: managers being less agreeable and more antagonistic; labourers being less conscientiousness; and sales people being more extraverted.
\end{abstract}

JEL Classification: J24, J62, C25

Keywords: occupational choice, personality traits, credentialism, dynasty hysteresis

Corresponding author:

Robert Wells

School of Economics and Finance

University of Western Sydney

Locked Bag 1797

Penrith South DC, NSW 1797

Australia

E-mail: R.Wells@uws.edu.au 


\section{Introduction ${ }^{1}$}

This paper examines occupational choice to test if an extended personality traits influence an individual's occupational choice, controlling for an array of other variables. Typically the heterogeneity of labour markets is examined by looking for compensating wage differentials as first advocated by Adam Smith in "an inquiry into the nature and cause of the wealth of nations” (1776, 1993 reprint) and hedonic wage theory (Lucas 1977). These approaches rely on labour markets being in equilibrium and completely reflecting the value of the individual's characteristics. However, the commonly used earnings functional form has flaws, especially in terms of measures of human capital inputs such as education (Heckman, Lochner \& Todd 2003). Further the use of equilibrium analysis in wages is questionable if wages are sticky, markets are imperfect and inhibited by various institutional and sociological factors (Akerlof \& Yellen 1990; Ehrenberg \& Smith 2006; Kaufman \& Hotchkiss 2006). Wages may take a long time to adjust (Friedman 2007) and observed wages may contain a large component of disequilibrium rents (Bowles, Gintis \& Osborne 2001a). It can also be argued that the wage determination does not directly lend itself to application by policy makers in terms of ways to improve labour force supplies and the outcomes of particular individuals.

An alternative is the occupational choice approach which focuses on examining the individual's choice behaviour in the heterogeneous labour market. It does this by examining the probability an individual will attain a particular occupation on the basis of their characteristics using discrete choice models. This approach has the advantage that it

\footnotetext{
${ }^{1}$ This paper uses unit record data from the Household, Income and Labour Dynamics in Australia (HILDA) Survey. The HILDA Project was initiated and is funded by the Australian Government Department of Families, Housing, Community Services and Indigenous Affairs (FaHCSIA) and is managed by the Melbourne Institute of Applied Economic and Social Research (MIAESR). The findings and views reported in this paper, however, are those of the authors and should not be attributed to either FaHCSIA or the MIAESR

The data used in this paper was extracted using the Add-On package PanelWhiz for Stata ${ }^{\circledR}$. PanelWhiz (http://www.PanelWhiz.eu) written by Dr. John P. Haisken-DeNew (john@PanelWhiz.eu). See HaiskenDeNew and Hahn (2006) for details. The PanelWhiz generated DO file to retrieve the data used here is available from me the authors on request. Any data or computational errors in the paper due to the authors.
} 
provides clear predictions as to what influences choice and outcomes and it lends itself to resolving possible shortages in various types of skilled labour and the formulation of policy particularly to minimizing “joblessness”.

The first empirical work in occupational choice using modern discrete choice econometrics is Boskin (1974) followed by Schmidt and Strauss (1975). There is limited econometric work in Australia (Vella 1993; Borooah \& Mangan 2002). The central tenet of these models, formalized by (Heckman \& Honore 1990; Gould 2002), is that individuals move to that occupation in which their particular characteristics are most productive and highest valued even if these characteristics are valued in all occupations.

There are various sources of heterogeneity in labour markets that can influence the productivity of an individual and, through wages and non-pecuniary factors, alter the utility of a specific occupation. The primary factor that has been examined as a source of heterogeneity between individuals is human capital. Becker (1993) argues that education, experience and various other skills can be seen as capital improvements like any other factor of production and therefore increase the productivity of an individual. The literature to date has usually measured education and experience in years. However, Heckman et al. (2003) posit that the effect of education may not be constant in years and that certain educational credentials may have non-linear effects. Shaw (1984) highlights that considering human capital to consist primarily of general education and job specific experience is limited. Leigh (2008) demonstrates that education credentials exhibit a nonlinear effect in years of education on earnings and labour force participation in Australia

An extension to human capital and occupational choice is the argument that the achievement of an individual's parents influences the behaviour, skills and abilities of an individual. That is, the status of an individual's parents is a source of potential heterogeneity. Due to this transference of characteristics between parents and offspring, individuals tend to have an increased probability of being in the same or similar occupations as their parents, ceteris paribus. This is known as dynasty hysteresis. The mechanism which is the underlying cause for dynasty hysteresis is subject to debate. 
Laband and Lentz (1983) argue that dynasty hysteresis is caused by human capital transfer which is more predominant in some occupations than others. Fan (2008) argues that dynasty hysteresis may be transmitted by religion and its associated characteristics. Akerlof (1997) puts forward a theory of social distance in which individuals have both a desire to excel and a desire to conform to their social group. Other potential mechanisms include the intergenerational transfer of preferences (Doepke \& Zilibotti 2005) and of non-cognitive factors (Bowles \& Gintis 2002). Irrespective of the transfer mechanism, dynasty is an important phenomenon to be examined in occupational choice as it has a crucial effect on the ability of an individual to have freedom to pursue any occupation they desire and the extent in which the other determinants influence the choice (Bradley 1991; Mazumder 2005; Bjerk 2007). Previous analyses of occupational choice have included parental variables to attempt to control for dynasty hysteresis (Robertson \& Symons 1990; Bradley 1991; Tsukahara 2007). By controlling for education and personality it may be possible to control and identify that dynasty hysteresis is just due to correlation of these variables across generations.

Human capital theory has recently expanded the search for sources of productive capabilities, notably cognitive intelligence. However, it appears that the effects of cognitive intelligence on wages are modest at best (Cawley et al. 1997; Cawley, Heckman \& Vytlacil 2001). Bowles, Gintis and Osborne (2001a) highlight that the modest returns to cognitive intelligence are not due to its lack of influence on productivity, but reflects the lack of scarcity of this characteristic. Heckman and Rubinstein (2001) refer to the lack of the effect of intelligence factors and argue from common sense that various behavioural characteristics, or as they call them non-cognitive skills, are important influences on labour market outcomes. Heckman and Rubinstein (2001) state these behavioural characteristics are the 'dark matter' of economics, a potentially powerful explanatory factor that is an under-examined area in economics.

It has been previously thought within economics that differences between individuals' characteristics, such as preferences, are far too numerous, and are not a sensible area, for the scientific examination of economic behaviour (Caplan 2003). This is not the case in 
psychology which has long sought to find and classify the differences between individuals' consistent and enduring behavioural characteristics; these are known as personality traits. The focus of this paper is an examination of the influence of personality traits on occupational choice by way of a standard multinomial logit model. The categorical variable, occupational category is measured as Australian and New Zealand standard classification of occupations (ANZSCO). The conditioning variables used include personality measures, educational achievement by way of qualifications gained, demographic and personal variables, parental characteristics, as well as controls for industry and location.

\section{Psychometrically Derived Personality Traits and Occupational Choice} McCrae and Costa (2003) provide a summary of the literature on the psychology of personality to date and argue, along with others (Digman 1990; Goldberg 1993; Caplan 2003; Cole 2007; Borghans et al. 2008a), that the general consensus model for personality traits is that of the five factor model (FFM). The FFM states that personality traits are "dimensions of individual differences in tendencies to show consistent patterns of thoughts, feeling, and actions” (McCrae \& Costa 2003, pp. 25). These personality traits are typically viewed as broad level dispositions or propensities, that is they are not the sole determinant of behaviour but should be viewed as a contributing factor in a ceteris paribus context. Caplan (2003) emphasizes that, whilst personality traits are an important aspect of the examination of economic activity, the incentives of economics should not be neglected. Personality traits consist of broad dispositional traits that can influence behaviour, this does not mean that individuals with the same level of personality traits are identical as the traits can manifest themselves in different specific mannerisms, or characteristics adaptations, as stated by McCrae and Costa (2003).

These five traits consist of Openness to experience, Conscientiousness, Extraversion, Agreeableness and Neuroticism ${ }^{2}$. Each of these traits have a corresponding negativeclosed to experience, carelessness, introversion, antagonism and emotional stabilitywhich correspond to low scores of the corresponding dimensions. It should be noted that

\footnotetext{
${ }^{2}$ This can be remembered with the mnemonic device OCEAN which corresponds to the order stated above.
} 
here emotionally stability is used in the place of neuroticism to preserve the original arrangement of the data. Openness to experience can be defined as a trait associated with being accepting of new ideas and alternative points of view, appreciation of new concepts, imaginative and creative and generally inquisitive and curious. Conscientiousness is the trait that is associated with diligence, self discipline, punctuality, organised and general competence ${ }^{3}$. Extraversion is the trait associated with being talkative, friendly, energetic and outgoing. This trait has been previous examined in economics by Krueger and Schkade (2008) and found to influence the occupational outcomes and wages. Agreeableness can be described as the tendency to be generous, warm, altruistic, tender, and complacent and tend to get along with others. Individuals with a lack of agreeableness can conversely be aggressive, tough and quite adversarial. Neuroticism is the last trait in the FFM, it is often commonly referred to by its negative of emotional stability, which shall be how it is used in the analysis contain within this article. Neuroticism can be described as the tendency of experiencing negative emotions more frequently and intensely. Neuroticism can be described as a trait associated with anxiety, worry, paranoia and stress. Traits associated with these dimensions of personality can been seen in table 1 from McCrae and Costa (2003)

\footnotetext{
${ }^{3}$ This trait is a precursor to the FFM model and was referred to as 'work' (Goldberg, 1993)
} 
Table 1: Characteristics of higher and lower scores in the personality traits of the Five Factor Model.

\begin{tabular}{|c|c|c|}
\hline Personality trait & Low Scorer & Higher scorer \\
\hline Openness & $\begin{array}{l}\text { Favours conservative values } \\
\text { Judges in conventional terms } \\
\text { Uncomfortable with complexities } \\
\text { Moralistic }\end{array}$ & $\begin{array}{l}\text { Values intellectual matters } \\
\text { Rebellious, nonconforming } \\
\text { Unusual thought processes } \\
\text { Introspective }\end{array}$ \\
\hline Conscientiousness & $\begin{array}{l}\text { Eroticizes situations } \\
\text { Unable to delay gratification } \\
\text { Self-indulgent } \\
\text { Engages in fantasy, daydreams }\end{array}$ & $\begin{array}{l}\text { Behaves ethically } \\
\text { Dependable, responsible } \\
\text { Productive } \\
\text { Has high aspiration levels }\end{array}$ \\
\hline Extraversion & $\begin{array}{l}\text { Emotionally bland } \\
\text { Avoids close relationship } \\
\text { Overcontrol of impulses } \\
\text { Submissive }\end{array}$ & $\begin{array}{l}\text { Talkative } \\
\text { Gregarious } \\
\text { Socially poised } \\
\text { Behaves assertively }\end{array}$ \\
\hline Agreeableness & $\begin{array}{l}\text { Critical, sceptical } \\
\text { Shows condescending behaviour } \\
\text { Tries to push limits } \\
\text { Expresses hostility directly }\end{array}$ & $\begin{array}{l}\text { Sympathetic, considerate } \\
\text { Warm, Compassionate } \\
\text { Arouses liking } \\
\text { Behaves in a giving away }\end{array}$ \\
\hline Neuroticism & $\begin{array}{l}\text { Calm, relaxed } \\
\text { Satisfied with self } \\
\text { Clear-cut personality } \\
\text { Prides self on objectivity }\end{array}$ & $\begin{array}{l}\text { Thin-skinned } \\
\text { Basically anxious } \\
\text { Irritable } \\
\text { Guilt-Prone }\end{array}$ \\
\hline
\end{tabular}

Source: McCrae and Costa, 2003

In psychology, research suggests that personality traits influence the choice of occupation by an individual (Barrick \& Mount 1991; Larson, Rottinghaus \& Borgen 2002; Barrick, Mount \& Gupta 2003; Ozer \& Benet-Martinez 2006; Furnham \& Fudge 2008). Barrick and Mount (1991) put forward a number of hypotheses in their meta-analysis of the effect of the FFM in regard to how personality variables influence an individual's productivity and consequently their occupational achievement. Conscientiousness is argued to carry a ubiquitous positive effect on labour market outcomes as individuals who possess this trait are often hardworking, productive, punctual, organised and accepting of responsibility. It can be argued that openness has an effect on the ability of individuals to be trained, being embracing of new ideas and consequently can be positively valued. Emotional stability is 
argued to influence an individual's occupation achievement via the individual being less likely to experience negative emotions and they can take on more stressful, non-routine and risky tasks. Barrick and Mount (1991) posit that agreeableness may be valued in some occupations as friendliness is desirable for interpersonal interaction; however, it has been argued that antagonistic personality may be required for certain tasks by both the supplier of and demander for labour (McCrae \& Costa 2003; Borghans, ter Weel \& Weinberg 2008b). In addition, it has been argued that Machiavellian tendencies, that is the ability and desire to manipulate people for benefit is positively valued in labour markets (Bowles et al. 2001a; Bowles, Gintis \& Osborne 2001b; Wakefield 2008). Extraversion may be valued in occupations that involve a large amount of interaction with other individuals as extraverted individuals would gain greater utility from these interactions (Barrick \& Mount 1991; Krueger \& Schkade 2008). The results of Barrick and Mount's (1991) meta-analysis show that conscientiousness and openness behave as predicted, extraversion is valued, in terms of job productivity, in both social jobs and training while agreeableness and neuroticism are observed to have no effect on labour market outcomes. They argue that the lack of an observed effect with regard to neuroticism may be due to a sample selection bias as you require a minimum amount of emotional stability -the negative of neuroticism- to achieve a position in the labour market.

One important issue is the stability of personality traits. McCrae and Costa (2003) present a comprehensive review of a large body of work which suggests that from the age of thirty personality is mostly stable within the broad definition of the FFM. With regard to specific aspects of personality traits, the five factors each comprise a number of smaller factors or facets which are specific aspects of that trait. In addition, these facets can also, depending on the test, consist of even finer aspects of personality traits. While the broad traits of the FFM are stable, their components are less stable; however, the changes in these finer order characteristic tend to average out leaving the broad factor stable. Thus, while a broad trait is stable, the way it manifests itself in specific behaviours may vary. Others argue that personality is endogenous and unstable and may be influenced by labour market factors (Mueller \& Plug 2004; Groves 2005; Heckman, Stixrud \& Urzua 
2006; Cole 2007; Semykina \& Linz 2007; Cunha \& Heckman 2008). However, this is due to the fact that they are using different traits derived from different personality models. The adult stability of personality traits as measured by the FFM complements the argument put forward for early invention in studies by Heckman and associates with productive personality traits and behavioural tendencies being influenced at a young age (Heckman 2000; Heckman 2006; Knudsen et al. 2006; Cunha \& Heckman 2008; Heckman 2008). Based on the FFM, this analysis treats adult personality as stable over the relatively short length (seven years) of the data.

\section{The Data}

The data source is the Household Income and Labour Dynamics in Australia (HILDA) longitudinal data set. The HILDA survey is an approximately one in one thousand sample of the Australian population consisting of 19,914 individuals in 7,682 households in sample Wave one (Watson 2009). The HILDA dataset contains an extremely rich set of variables which capture details on a large number of individual characteristics including the focus of this study occupational and labour market outcomes, education, parental status, and standard demographics variables. Particularly, it contains a comprehensive set of personality measures which conform with the FFM. These were derived, following the well established procedures of the FFM, using a factor analysis of underlying variables.

Occupations in the HILDA data are coded into the ANZSCO system. The HILDA data in its general release provide the ANZSCO coding at both the one digit and two digit levels. This research uses the one digit ANZSCO coding which consists of eight mutually exclusive and exhaustive occupational outcomes. The eight one digit categories are managers, professionals, technicians and tradespersons, community and personal service workers, clerical and administrative workers, sales workers, machine operators and drivers, and labourers. Each of these categories describes a set of skill specialisations that are relative homogenous compared with other groups. These categories give a good representation of occupations based on the view that an occupation is a set of relatively homogenous tasks A brief description of each of these eight occupational categories and examples of jobs that fall into these categories can be seen in Table 2 . 
Table 2: Definitions and examples of the ANZSCO coding of occupations.

\begin{tabular}{|c|c|c|}
\hline Occupation (abbreviations underlined) & Description of tasks & Examples \\
\hline Managers & $\begin{array}{l}\text { Plan, organize, coordinate and review various } \\
\text { operations }\end{array}$ & $\begin{array}{l}\text { General manager, legislators, farm manager, finance } \\
\text { managers, retail manager, \& customer service manager }\end{array}$ \\
\hline Professionals & $\begin{array}{l}\text { analytical, conceptual and creative tasks } \\
\text { require the application of a body of } \\
\text { knowledge }\end{array}$ & $\begin{array}{l}\text { Actors, airline pilots, Engineers, Physical and social } \\
\text { Scientists, Medical professionals, lawyers, IT professionals, } \\
\text { and educators }\end{array}$ \\
\hline Technicians and tradespersons & $\begin{array}{l}\text { Skilled tasks requiring broad or specific } \\
\text { knowledge. }\end{array}$ & $\begin{array}{l}\text { Scientific Technicians, motor mechanics, construction } \\
\text { workers, chefs, florists and hairdressers }\end{array}$ \\
\hline Community and personal service workers & $\begin{array}{l}\text { Provision of service to either individuals } \\
\text { personally or the community as a whole that } \\
\text { often requires interaction with others. }\end{array}$ & $\begin{array}{l}\text { Paramedics, child carers, baristas, waiters, security officer, } \\
\text { military personnel, driving instructors and sportspersons. }\end{array}$ \\
\hline Clerical and administrative workers & $\begin{array}{l}\text { Organize, store, manipulate and retrieve } \\
\text { information }\end{array}$ & $\begin{array}{l}\text { Office managers, data entry clerks, receptionists, payroll } \\
\text { clerk, mail clerks and proofreader }\end{array}$ \\
\hline Sales workers & $\begin{array}{l}\text { Sell goods and services and provide sales } \\
\text { support }\end{array}$ & $\begin{array}{l}\text { Sales representative, insurance brokers, retail supervisors, } \\
\text { checkout operator, models and telemarketers, }\end{array}$ \\
\hline Machinery operators and drivers & $\begin{array}{l}\text { Operate machinery, plant vehicles and other } \\
\text { equipment }\end{array}$ & $\begin{array}{l}\text { Industrial spraypainter, sewing machinist, motion picture } \\
\text { projectionist, crane operator, forklift driver, and train driver }\end{array}$ \\
\hline Labourers & $\begin{array}{l}\text { Repetitive and routine tasks that may include } \\
\text { the use of hand or power tools. }\end{array}$ & $\begin{array}{l}\text { Cleaners, steel fixer, product assembler, packer, slaughter, } \\
\text { farm worker, kitchen hand, freight handler and handypersons }\end{array}$ \\
\hline
\end{tabular}

While these groups are relatively homogeneous in terms of tasks, some occupations can be expected to have differing desired characteristics; for example, security workers are in the same category as baristas. Analysis of the two digit level of 43 categories would capture some of the heterogeneity in the broader class. However, analysis at the two digit level leads to difficulties given the necessary number of parameters, a low frequency of observation in particular states, and possible violation of necessary conditions for the model's adequacy. For these reasons this current work is limited to occupational categories at the one digit level.

As well as personality trait measures the HILDA data gives very detailed listings of variables that theory elects as important in conditioning occupational outcomes. As well as the standard demographic variables such as age, gender, location, marital status, etc., the HILDA survey dataset contains data on the education attainment of an individual in 
terms of qualifications. In order to capture occupation specific human capital and to introduce non-linearity into the influence of education on labour market outcomes the analysis uses a series of binary variables based on educational achievement.

Two sets of variables are used to capture parental status. The first is the labour market success of an individual's parents. This is measured by a set of binary variables which reflect the occupation an individual's mother and father. Of particular interest is the probability of an individual being in the same occupation as their parent, this would provide support of the phenomenon of dynasty hysteresis. The second is the AUSEI06 measure of social status. This is an index ranging between zero and one hundred, to one decimal place, which incorporates a variety of education, occupation, income and other demographic effects that reflect an individual's social success (Jones \& McMillan 2001; McMillan, Jones \& Beavis 2008). The AUSEI06 allows for a continuous version of parental status to be used in order to determine if it influence an individual's occupational outcome.

Prior to presenting tables of measures and summary statistics which describe the data, it would be useful to return to the personality data. The HILDA dataset provides a rich array of variables that are rare within a nationally representative dataset to examine the “dark matter" of economics of personality factors (Heckman \& Rubinstein 2001). The survey administered a questionnaire based on the FFM in Wave five. The test takes 30 questions consisting of adjectives that describe the respondent's typical behaviour from the mini-marker test developed by Saucier (1994) and 6 questions from other valid personality tests. These personality tests are usually subjected to standard tests in order to ensure that they are valid psychometric instruments and can be used for meaningful analysis of unobserved psychological phenomena and are not purely mathematical constructs (Borghans et al. 2008a). The personality test in HILDA are no exception and Losoncz (2007) provides an assessment of the validity of the personality tests and finds that the derived psychometric instruments are valid. 
Table 3: The Frequency of Occupations

\begin{tabular}{|l|c|c|}
\hline \multicolumn{1}{|c|}{ Occupation } & Frequency & Percentage \\
\hline Managers & 4,234 & 13.56 \\
\hline Professionals & 8,259 & 26.44 \\
\hline Technicians and Trades Workers & 3,905 & 12.5 \\
\hline Community and Personal Service Work & 3,053 & 9.78 \\
\hline Clerical and Administrative Workers & 5,014 & 16.05 \\
\hline Sales Workers & 2,636 & 8.44 \\
\hline Machinery Operators and Drivers & 1,599 & 5.12 \\
\hline Labourers & 2,531 & 8.1 \\
\hline
\end{tabular}

Table 4: Summary Statistics

\begin{tabular}{|l|r|r|r|r|}
\hline \multicolumn{1}{|c|}{ Variable } & \multicolumn{1}{c|}{ Mean } & \multicolumn{1}{c|}{ S.D. } & Min. & Max. \\
\hline Age & & & & \\
\hline Age & 39.1873 & 12.4450 & 15 & 83 \\
\hline Age Squared & 4.4876 & 1.0806 & 1 & 7 \\
\hline Personality & & & & \\
\hline Agreeableness & 5.3658 & 0.8791 & 1 & 7 \\
\hline Openness & 5.1154 & 1.0137 & 1 & 7 \\
\hline Conscientiousness & 5.1378 & 1.0419 & 1 & 7 \\
\hline Extraversion & 4.3256 & 1.0196 & 1 & 7 \\
\hline Emotional Stability & 1690.5180 & 1003.9180 & 225 & 6889 \\
\hline Parental Status & & & & \\
\hline Father's AUSEI06 & 46.3126 & 22.8780 & 0 & 100 \\
\hline Mother AUSEI06 & 43.0612 & 23.1785 & 3.4 & 100 \\
\hline
\end{tabular}

Table 3 gives the frequency and relative frequency counts for occupational status categories used in the multinomial logit. The preponderance of professionals and clerical and administrative workers reflects the distribution of occupations in the population and mirrors outcomes of other Australian surveys. Table 4 contains summary statistics for those variables where these measures are meaningful. Table 5 summarises the binary variables used in the analysis. For each binary variable the proportion scores are the proportion scoring one. 
Table 5: Binary Variables

\begin{tabular}{|c|c|c|c|c|c|}
\hline Variable & Proportion & Variable & Proportion & n Variable & Proportion \\
\hline Gender (Base: male) & & Industry (Base: Manufacturing) & & $\begin{array}{l}\text { Father's occupation (Base: } \\
\text { Professional) }\end{array}$ & \\
\hline Female & 0.4935 & Agriculture & 0.0384 & Father Manager & 0.2519 \\
\hline $\begin{array}{l}\text { Education (Base: Year } \\
\text { 12) }\end{array}$ & & Mining & 0.0134 & Father Technician & 0.2423 \\
\hline PhD or master & 0.0470 & Electricity, gas and water & 0.0087 & Father Service & 0.0357 \\
\hline Graduate diploma & 0.0738 & Construction & 0.0680 & Father Clerical & 0.0627 \\
\hline Bachelor & 0.1716 & Wholesale trade & 0.0326 & Father Sales & 0.0478 \\
\hline Advanced diploma & 0.1048 & Retail trade & 0.0945 & Father Operator & 0.0993 \\
\hline Certificate 3 or 4 & 0.2034 & $\begin{array}{l}\text { Accommodations and food } \\
\text { service }\end{array}$ & 0.0569 & Father labourer & 0.0888 \\
\hline Certificate 1 or 2 & 0.0113 & Transport & 0.0405 & $\begin{array}{l}\text { Mother's occupation (Base: } \\
\text { Professional) }\end{array}$ & \\
\hline Certificate not applicable & 0.0023 & Telecommunications & 0.0295 & Mother Manager & 0.0985 \\
\hline Year 11 or Less & 0.2276 & Finance & 0.0381 & Mother Technician & 0.0768 \\
\hline State (Base: NSW) & & Real estate & 0.0131 & Mother Service & 0.0834 \\
\hline Victoria & 0.2512 & Scientific and technical & 0.0830 & Mother Clerical & 0.2327 \\
\hline Queensland & 0.2092 & Admin and support & 0.0263 & Mother Sales & 0.1175 \\
\hline South Australia & 0.0841 & Public admin & 0.0713 & Mother Operator & 0.0338 \\
\hline Western Australia & 0.0962 & Education & 0.1159 & Mother labourer & 0.1643 \\
\hline Tasmania & 0.0311 & Healthcare and social status & 0.1225 & Year (Base: 2001) & \\
\hline Northern Territory & 0.0070 & Arts and recreation & 0.0187 & 2002 & 0.1315 \\
\hline $\begin{array}{l}\text { Australian Capital } \\
\text { Territory }\end{array}$ & 0.0251 & Other & 0.0375 & 2003 & 0.1375 \\
\hline $\begin{array}{l}\text { Marital Status (Base: } \\
\text { Single) }\end{array}$ & & $\begin{array}{l}\text { Country of Origin (Base } \\
\text { Australia) }\end{array}$ & 0.0375 & 2004 & 0.1445 \\
\hline Married & 0.5580 & English Speaking country of orgin & 0.1152 & 2005 & 0.1632 \\
\hline Defacto & 0.1416 & Non-English country of origin & 0.0737 & 2006 & 0.1520 \\
\hline Separated & 0.0284 & & & 2007 & 0.1475 \\
\hline Divorced & 0.0531 & & & & \\
\hline Widow & 0.0084 & & & & \\
\hline
\end{tabular}

\section{Estimation and Results}

A multinomial logit model was estimated using STATA 10. The estimate was normalized on the modal occupation, professional. Using the test proposed by Long and Freese (2006) in their SPOST suite of STATA commands (not reported), which is a test based on the Cramer-Ridder test (Cramer \& Ridder 1991), it can be concluded that none of the occupational states can be pooled together, suggesting that no further aggregation is possible without biasing the results.. Based on this, one should not expect violations of the independence of irrelevant alternatives (IIA) assumption Rather than report the rather large numbers of estimated coefficients the marginal effects alone are reported. The analysis used the marginal effects estimated by the MARGEFF 
module used (Bartus 2005). Further, these are the mean marginal effects for the sample data rather than the marginal effects at means. For brevity, the average marginal effects for the personality traits, the focus of this study, are presented in table 6 in the text. All other average marginal effects are reported and discussed in separate tables in the Appendix.

Table 6: Average Marginal Effects Personality Traits

\begin{tabular}{|l|l|l|l|l|}
\hline Variable & Managers & Professionals & Technician & Service \\
\hline Openness & $0.00598^{* * *}$ & $0.01127^{* * *}$ & 0.00153 & -0.00043 \\
\hline Conscientiousness & $0.01205^{* * *}$ & -0.00027 & 0.00156 & -0.00077 \\
\hline Extraversion & $0.01447^{* * *}$ & -0.00147 & 0.0013 & -0.00009 \\
\hline Agreeableness & $-0.01481^{* * *}$ & -0.00144 & $-0.00345^{*}$ & $0.00351^{*}$ \\
\hline Emotional Stability & 0.00186 & $0.00694^{* * *}$ & -0.00248 & 0.00242 \\
\hline & Clerical & Sales & Operator & Labourer \\
\hline Openness & $-0.00964^{* * *}$ & -0.00046 & $-0.00421^{* * *}$ & $-0.00404^{* *}$ \\
\hline Conscientiousness & $0.00664^{* * *}$ & $-0.00826^{* * *}$ & $-0.00312^{* *}$ & $-0.00783^{* * *}$ \\
\hline Extraversion & $-0.01353^{* * *}$ & $0.00556^{* * *}$ & -0.00008 & $-0.00616^{* * *}$ \\
\hline Agreeableness & $0.00750^{* * *}$ & $0.00404^{* *}$ & $0.00593^{* * *}$ & -0.00129 \\
\hline Emotional Stability & $-0.00824 * * *$ & -0.00182 & -0.00025 & 0.00157 \\
\hline Controls (see Appendix) & & & & \\
\hline Observations & 31,231 & & $\mathbf{P s e u d o ~ \mathbf { R } ^ { 2 }}$ & 0.3705 \\
\hline Legend & $* \mathbf{p}<\mathbf{0 . 1}$ & $\boldsymbol{*} \mathbf{p}<\mathbf{0 . 0 5}$ & $* * * \mathbf{p}<\mathbf{0 . 0 1}$ & \\
\hline
\end{tabular}

Personality traits, discussion: Table 6 indicates that personality traits generally seem to have some influence on occupational outcomes with the average marginal effects frequently being statistically significant for traits and occupations.

Openness to experience, a trait related to receptiveness to training and accepting of new and different ideas, significantly increases the probability of individuals being found in management or professional roles. This is to be expected as both require individuals to deal with a variety of ideas, be accepting of new ideas and concepts and require training, as can be seen from Table 1. The trait openness also tends to reduce the probability of an individual being an operator and labourer. The tasks of an operator or labourer, as seen in Table 1, tend to involve only a set of routine tasks thus openness would not be highly valued by employers. It is possible that individuals who tend not to be receptive to new 
idea may choose jobs within these occupations as it allows for a narrow specialisation and consists primarily of a routine body of tasks. The average marginal effect for openness is relative important in terms of magnitude with an effect. For example for professional moving from the lowest possible score, one, to the highest, seven, gives an increase of 0.068 which is similar to the average marginal effect of completion of high school on the probability of being in a professional occupation, see table A1 in the appendix.

Conscientiousness, the trait associated with hard work and effort, is found to significantly increase the probability of an individual being in a management or clerical position and decrease the probability of an individual being a salesperson, operator or labourer. One aspect of the personality trait conscientiousness is the ability to plan and be organised, an aspect that is central to the tasks performed in both management and clerical roles. Thus despite the trait being valuable in all labour market outcomes, as in Roy’s (1951) model, people tend towards these occupation and are drawn away from those of salesperson, operators and labourers. The magnitude of the effects of conscientiousness are quite sizeable with an effect moving from the lowest level to the highest level of this trait being a 0.0723 increase in the probability of being in a management occupation which has a greater effect than having a bachelors degree, 0.063, but lesser than a graduate diploma, 0.109 or PhD or masters, 0.206, on being in this occupation. See Table A1 in the appendix for these scores. This result highlights the potential for personality factors to matter more than traditional human capital variables.

Extraversion, the trait associated with being outgoing and desiring to engage with other individuals is found to significantly affect some occupational outcomes. Individuals who are observed with higher level of extraversion have a higher probability of being in management and in sales while a lower probability of being in clerical or labourer occupations. These results make sense in that sales roles necessitate social interactions. In addition, management entails, as can be seen in Table 1, the organising of resources to complete tasks such as human labour and thus requires social interaction. Conversely, clerks and labourers tasks are generally not focused on interacting with others, and thus 
individuals who prefer less social interaction would tend to select these occupations. The effects of extraversion can matter more than a bachelor degree in the probability of being a manager with similar size effects for clerical occupations.

Agreeableness has a negative effect on the probability of an individual being a manager or technician (albeit at the $10 \%$ level for the latter). As suggested earlier, certain occupations would tend to favour individuals who are concerned with pleasing others. This can include occupations in which there is a greater focus on task completion and competition rather than interacting with others. This would include management and to a lesser extent technical positions. Conversely, individuals with high levels of agreeableness tend to be found in occupations of service, clerical, sales and operators. Sales and service were both expected to be effected by agreeableness as both are social occupations that require interpersonal interactions. It should be noted that individuals in many community service roles, such as security, police and military service, could benefit from being antagonistic. In addition to these social occupations, operators and clerks both have high levels of agreeableness. This could be both due to the fact that these occupations require more teamwork or that individual with lower agreeableness tend to be able to progress into management roles at the expensive of their more agreeable counterparts.

Emotional stability, the negative of neuroticism is a trait associated with being less likely to experience negative emotions, and like all the other personality traits of the five factor model, has a significant effect on occupational choice. Individuals, who exhibit higher levels of emotional stability, tend to be professionals while those with lower levels of emotional stability tend to work as clerical workers. This result seems to make sense as professional work involves a higher number of complex tasks requiring expert knowledge and independent thought which may be non-routine and stressful. The opposite can be expected with clerical occupations. In addition, this occupation is likely to be less risky, a factor known to influence occupational choice (DeLeire \& Levy 2004). 
Personality significantly influences the probability of an individual choosing, or being chosen for, a particular occupation, with each trait influencing at least one occupational outcome and all outcomes being influenced by at least one personality trait, at the ten percent significant level. Generally these effects are found to be modest in comparison to human capital but they can rival education credentials in certain occupations. Due to the persistence of personality effects in all occupations, we argue that personality effects are relatively more important than parental status; the effects of parent's social status tend to be similar if not smaller in magnitude and less persistent. It is possible that the findings with regards to personality are suppressed as personality and parental status may also influence education and thus the indirect effect of personality is not fully captured by the current model. With regards to occupations, management tends to be most influenced by personality traits and this may reflect the lack of requirements of formal qualifications in many management positions.

Because personality traits are the source of novelty in this research, discussion of the results for other influences on occupational are left to the Appendix. However, in summary, it can be found that labour market heterogeneity is important as individuals are sorted between occupations based on the various other different characteristics nominated by theory and incorporated in the multinomial logit model. The results broadly indicate that education does exhibit a non-linear effect in years with arguably occupation specific education and that parental status and a small and limited scope of effects in occupational outcomes.

\section{Conclusion}

This paper examines the effect of human capital, parental status and personality on occupational outcomes for a representative panel of Australian households. Economic theory argues that individuals should select the occupation that grants them the highest utility and that because both individuals and tasks in the labour markets are quite heterogeneous individuals must be sorted. Using a multinomial logit model, it is found that human capital exhibits a non-linear effect on occupational attainment, parental status has a limited influence and the broad personality traits of the highly validated five factor 
model have a significant, relatively strong, persistent and expected effect over occupational outcomes. Further developments can include use of a finer level of disaggregation of occupations; introducing jobless individuals into the analysis; expansion into the dynamics of occupational choice exploiting transition between occupations captured in longitudinal data. There is also scope for separating out the direct and the indirect effects, through education, of personality and parental status on occupational choice. Further, an important addition would be decomposition into the supply side and demand side effects of variables on occupational choice.

\section{References}

Akerlof, G. A. 1997, 'Social distance and social decisions.' Econometrica, Vol. 65, No. 5, pp. 1005-1027.

Akerlof, G. A. \& Yellen, J. L. 1990, 'The fair wage-effort hypothesis and unemployment.' Quarterly Journal of Economics, Vol. 105, No. 2, pp. 255-283.

Barrick, M. R. \& Mount, M. K. 1991, 'The big five personality dimensions and job performance: a meta-analysis.' Personnel Psychology, Vol. 44, No. 1, pp. 1-26.

Barrick, M. R., Mount, M. K. \& Gupta, R. 2003, 'Meta-analysis of the relationship between the five-factor model of personality and Holland's occupational types.' Personnel Psychology, Vol. 56, No. 1, pp. 45-74.

Bartus, T. 2005, 'Estimation of marginal effects using margeff.' The Stata Journal, Vol. 5, No. 3, pp. 309-329.

Becker, G. S. 1993. Human capital: a theoretical and empirical analysis, with special reference to education, Chicago, The University of Chicago Press.

Bjerk, D. 2007, 'The differing nature of black-white wage inequality across occupational sectors.' Journal of Human Resources, Vol. 42, No. 2, pp. 398-434.

Borghans, L. et al. 2008a, 'The Economics and Psychology of Personality Traits.' Journal of Human Resources, Vol. 43, No. 4, pp. 972-1059.

Borghans, L., ter Weel, B. \& Weinberg, B. A. 2008b, 'Interpersonal Styles and Labor Market Outcomes.' Journal of Human Resources, Vol. 43, No. 4, pp. 815-858. 
Borooah, V. K. \& Mangan, J. 2002, 'An analysis of occupational outcomes for indigenous and asian employees in Australia.' The Economic Record, Vol. 78, No. 1, pp. 31-49.

Boskin, M. J. 1974, 'A conditional logit model of occupational choice.' The Journal of Political Economy, Vol. 82, No. 2, pp. 389-398.

Bowles, S. \& Gintis, H. 2002, 'The inheritance of inequality.' Journal of Economic Perspectives, Vol. 16, No. 3, pp. 3-30.

Bowles, S., Gintis, H. \& Osborne, M. 2001a, 'The determinants of earnings: a behavioral approach.' Journal of Economic Literature, Vol. 39, No. 4, pp. 1137.

Bowles, S., Gintis, H. \& Osborne, M. 2001b, 'Incentive-enhancing preferences: personality, behavior, and earnings.' American Economic Review, Vol. 91, No. 2, pp. 155-158.

Bradley, S. 1991, 'An empirical analysis of occupational expectations.' Applied Economics, Vol. 23, No. 7, pp. 1159.

Caplan, B. 2003, 'Stigler-Becker versus Myers-Briggs: why preference-based explanations are scientifically meaningful and empirically important.' Journal of Economic Behavior \& Organization, Vol. 50, No. 4, pp. 391-405.

Cawley, J. et al. 1997, 'Cognitive ability, wages, and meritocracy', in Intelligence, genes, and success : scientists respond to "The bell curve". B. Devlin Springer, New York.

Cawley, J., Heckman, J. \& Vytlacil, E. 2001, 'Three observations on wages and measured cognitive ability.' Labour Economics, Vol. 8, No. 4, pp. 419-442.

Cole, K. 2007, Good for the soul: the relationship between work, wellbeing and psychological capital, PhD in Economics, University of Canberra

Cramer, J. S. \& Ridder, G. 1991, 'Pooling states in the multinomial logit model.' Journal of Econometrics, Vol. 47, No. 2-3, pp. 267-272.

Cunha, F. \& Heckman, J. J. 2008, 'Formulating, Identifying and Estimating the Technology of Cognitive and Noncognitive Skill Formation.' Journal of Human Resources, Vol. 43, No. 4, pp. 738-782.

DeLeire, T. \& Levy, H. 2004, 'Worker sorting and the risk of death on the job.' Journal of Labor Economics, Vol. 22, No. 4, pp. 925-953. 
Digman, J. M. 1990, 'Personality structure: Emergence of the five-factor model.' Annual Review of Psychology, Vol. 41, No. 1, pp. 417.

Doepke, M. \& Zilibotti, F. 2005, 'Social class and the spirit of capitalism.' Journal of the European Economic Association, Vol. 3, No. 2/3, pp. 516-524.

Ehrenberg, R. G. \& Smith, R. S. 2006. Modern labour economics: theory and public policy, Pearson Education.

Fan, C. S. 2008, 'Religious participation and children's education: a social capital approach.' Journal of Economic Behavior \& Organisation Vol. 65, pp. 303-317.

Friedman, M. 2007. Price theory, New Brunswick, NJ, Transaction Publishers.

Furnham, A. \& Fudge, C. 2008, 'The five factor model of personality and sales performance.' Journal of Individual Differences, Vol. 29, No. 1, pp. 11-16.

Goldberg, L. R. 1993, 'The structure of phenotypic personality traits.' American Psychologist, Vol. 48, No. 1, pp. 26-34.

Gould, E. D. 2002, 'Rising wage inequality, comparative advantage, and the growing importance of general skills in the united states.' Journal of Labor Economics, Vol. 20, No. 1, pp. 105.

Groves, M. O. 2005, 'How important is your personality? Labor market returns to personality for women in the US and UK.' Journal of Economic Psychology, Vol. 26, No. 6, pp. 827-841.

Heckman, J. J. 2000, 'Policies to foster human capital.' Research in Economics, Vol. 54, No. 1, pp. 3-56.

Heckman, J. J. 2006, 'Catch 'em young.' The Wall Street Journal, A, Vol. 15, pp. 14.

Heckman, J. J. 2008, Schools, skills and synapses, IZA Discussion paper, Bonn, Germany

Heckman, J. J. \& Honore, B. E. 1990, 'The empirical content of the roy model.' Econometrica, Vol. 58, No. 5, pp. 1121-1149.

Heckman, J. J., Lochner, L. \& Todd, P. E. 2003, Fifty years of Mincer earnings regressions, NBER Working papers, Cambridge, Massachusetts

Heckman, J. J. \& Rubinstein, Y. 2001, 'The importance of noncognitive skills: lessons from the GED testing program.' American Economic Review, Vol. 91, No. 2, pp. 145-149. 
Heckman, J. J., Stixrud, J. \& Urzua, S. 2006, 'The effects of cognitive and noncognitive abilities on labor market outcomes and social behavior.' Journal of Labor Economics, Vol. 24, No. 3, pp. 411.

Jones, F. L. \& McMillan, J. 2001, 'Scoring occupational categories for social research: A review of current practice, with Australian examples.' Work Employment Society, Vol. 15, No. 3, pp. 539-563.

Kaufman, B. E. \& Hotchkiss, J. L. 2006. The economics of labor markets, Mason, OH, Thomson/South-Western.

Knudsen, E. I. et al. 2006, 'Economic, Neurobiological, and Behavioral Perspectives on Building America's Future Workforce.' Proceedings of the National Academy of Sciences of the United States of America, Vol. 103, No. 27, pp. 10155-10162.

Krueger, A. B. \& Schkade, D. 2008, 'Sorting in the Labor Market.' Journal of Human Resources, Vol. 43, No. 4, pp. 859-883.

Laband, D. N. \& Lentz, B. F. 1983, 'Like father, like son: toward an economic theory of occupational following.' Southern Economic Journal, Vol. 50, No. 2, pp. 474.

Larson, L. M., Rottinghaus, P. J. \& Borgen, F. H. 2002, 'Meta-analyses of big six interests and big five personality factors.' Journal of Vocational Behavior, Vol. 61, No. 2, pp. 217-239.

Leigh, A. 2008, 'Returns to education in Australia.' Economic papers, Vol. 27, No. 3, pp. 233.

Long, J. S. \& Freese, J. 2006. Regression models for categorical dependent variables using Stata, College Station, Texas, Stata Press.

Losoncz, I. 2007 'Personality Traits in HILDA', HILDA survey research conference, University of Melbourne,

Lucas, R. E. B. 1977, 'Hedonic wage equations and psychic wages in the returns to schooling.' American Economic Review, Vol. 67, No. 4, pp. 549-558.

Mazumder, B. 2005, 'Fortunate sons: new estimates of intergenerational mobility in the united states using social security earnings data.' Review of Economics \& Statistics, Vol. 87, No. 2, pp. 235-255.

McCrae, R. R. \& Costa, P. T. 2003. Personality in adulthood : a five-factor theory perspective, New York, Guilford Press. 
McMillian, J., Jones, F. L. \& Beavis, A. 2008 'The AUSEI06: A new socioeconomic index for Australia', The annual conference of The Australian Sociological Association, University of Melbourne, Victoria, TASA,

Mueller, G. \& Plug, E. 2004, Estimating the effect of personality on male-female earnings, IZA Discussion paper, Bonn, Germany

Ozer, D. J. \& Benet-Martinez, V. 2006, 'Personality and the prediction of consequential outcomes.' Annual Review of Psychology, Vol. 57, No. 1, pp. 401-421.

Robertson, D. \& Symons, J. 1990, 'The occupational choice of British children.' Economic Journal, Vol. 100, No. 402, pp. 828-841.

Roy, A. D. 1951, 'Some thoughts on the distribution of earnings.' Oxford Economic Papers, Vol. 3, No. 2, pp. 135-146.

Saucier, G. 1994, 'Mini-markers: a brief version of Goldberg's unipolar big-five markers.' Journal of Personality Assessment, Vol. 63, No. 3, pp. 506.

Schmidt, P. \& Strauss, R. P. 1975, 'The prediction of occupation using multiple logit models.' International Economic Review, Vol. 16, No. 2, pp. 471-486.

Semykina, A. \& Linz, S. J. 2007, 'Gender differences in personality and earnings: evidence from Russia.' Journal of Economic Psychology, Vol. 28, No. 3, pp. 387410.

Shaw, K. L. 1984, 'A formulation of the earnings function using the concept of occupational investment.' The Journal of Human Resources, Vol. 19, No. 3, pp. 319-340.

Shaw, K. L. 1987, 'Occupational change, employer change, and the transferability of skills.' Southern Economic Journal, Vol. 53, No. 3, pp. 702.

Smith, A. 1993. An inquiry into the nature and causes of the wealth of nations, Oxford ; New York, Oxford University Press.

Tsukahara, I. 2007, 'The effect of family background on occupational choice.' Labour, Vol. 21, No. 4-5, pp. 871-890.

Vella, F. 1993, 'Gender roles, occupational choice and gender wage differential.' Economic Record, Vol. 69, No. 207, pp. 382.

Wakefield, R. L. 2008, 'Accounting and Machiavellianism.' Behavioral Research in Accounting, Vol. 20, No. 1, pp. 115. 
Watson, N. (Ed), HILDA user manual - release 7, Melbourne institute of applied economic and social research, University of Melbourne,

\section{Appendix}

Table A1: Human Capital Variables

\begin{tabular}{|c|c|c|c|c|}
\hline Variable & Managers & Professional & Technician & Service \\
\hline Age & $0.01258 * * *$ & -0.00071 & $-0.00296 * * *$ & $-0.00265 * * *$ \\
\hline Age squared & $-0.00011^{* * *}$ & 0.00001 & 0.00002 & 0.00001 \\
\hline PhD or Masters & $0.20595 * * *$ & $0.30553 * * *$ & $-0.06388 * * *$ & $-0.09727 * * *$ \\
\hline Graduate diploma & $0.10870 * * *$ & $0.28661 * * *$ & $-0.03579 * * *$ & $-0.09567 * * *$ \\
\hline Bachelor & $0.06334 * * *$ & $0.28609 * * *$ & $-0.02618 * * *$ & $-0.08175 * * *$ \\
\hline Advanced diploma & $0.02588 * * *$ & $0.09155 * * *$ & $0.03174 * * *$ & 0.00795 \\
\hline Certificate 3 or 4 & $-0.02447 * * *$ & $-0.03507 * * *$ & $0.13930 * * *$ & $0.03043 * * *$ \\
\hline Certificate 1 or 2 & $-0.02863 *$ & $-0.10447 * * *$ & 0.02168 & 0.01626 \\
\hline Certificate NA & 0.02 & $-0.12212 * * *$ & -0.03859 & 0.0183 \\
\hline \multirow[t]{2}{*}{ Year 11 or less } & $-0.02669 * * *$ & $-0.08884 * * *$ & $0.00984 *$ & -0.00484 \\
\hline & Clerical & Sales & Operator & Labourer \\
\hline Age & 0.00189* & $-0.00668 * * *$ & $0.00325 * * *$ & $-0.00472 * * *$ \\
\hline Age squared & -0.00001 & $0.00007 * * *$ & $-0.00004 * * *$ & $0.00005 * * *$ \\
\hline PhD or Masters & $-0.18301 * * *$ & $-0.04373 * * *$ & $-0.05088 * * *$ & $-0.07270 * * *$ \\
\hline Graduate diploma & $-0.16158 * * *$ & $-0.01468 *$ & $-0.03062 * * *$ & $-0.05696 * * *$ \\
\hline Bachelor & $-0.14686 * * *$ & $-0.01738 * * *$ & $-0.04341 * * *$ & $-0.03386 * * *$ \\
\hline Advanced diploma & $-0.08978 * * *$ & $-0.01102 * *$ & $-0.03465 * * *$ & $-0.02168 * * *$ \\
\hline Certificate 3 or 4 & $-0.07860 * * *$ & $-0.01158 * * *$ & -0.00398 & $-0.01603 * * *$ \\
\hline Certificate 1 or 2 & $-0.03478 *$ & -0.00614 & $0.04600 * * *$ & $0.09007 * * *$ \\
\hline Certificate NA & 0.04256 & -0.00995 & 0.05958 & 0.02798 \\
\hline Year 11 or less & -0.00235 & $0.00796 * *$ & $0.03672 * * *$ & $0.06819 * * *$ \\
\hline Legend & $* \mathrm{p}<0.1$ & $* * \mathrm{p}<0.05$ & $* * * \mathbf{p}<\mathbf{0 . 0 1}$ & \\
\hline
\end{tabular}

Human capital variables seem to exhibit significant effects on occupational choice. Age seems to increase, at a decreasing rate, the probability of an individual being a manager, clerical worker or operator while decreasing the probability of all other occupations significantly, with the exception of professionals. This is expected as these occupations relative to salespersons, labourers and service workers may require less physical exertion. It can also be seen as promotion with individuals moving across these occupations with experience. The size of these effects can be large with an extra decade increasing the probability of being in management by about 0.11 . This finding does confirm previous 
research that potential experience influences labour market outcomes such as occupational choice.

Education is specified as a series of education credentials in order to capture any possible non-linearity and occupational specific capital that would not be captured using the standard specification of education measured in years. It should be noted that all the effects of education are relative to that of an individual with a complete high school education. University level education, consisting of $\mathrm{PhD}$ or masters, graduate diploma and the bachelor degree, have a strong positive effect on the probability of an individual being in a profession and, to a less extent, manager. The estimated model suggests that the possession of university level education credentials draws individuals away from all other occupations fairly equally with the exception of large decrease in the probability of being a clerical worker. This result is expected as professionals, Table 1 in the text, require the completion of conceptual, creative and analytical tasks based on a body of knowledge. This body of knowledge is typically gained from university education and is very important for professionals. The effects on management are also expected but are due individuals 'rising through the ranks' to management positions. Education credentials also exhibit some non-linearity, in terms of years, and some occupation specific human capital. Advanced diploma and certificates 3 or 4 are an after high school qualification from technical colleges associated with the acquisition of a trade, technical or other applied skills. This credential has a significant positive effect on technician or service occupations but having a certificate 3 or 4 actually decreases the probability of being in a profession or management occupation relative to that of a high school graduate. This suggests that education does not just exhibit a constant linear effect and may possess occupational specific components.

Other possible occupation specific effects can be the increase probability of being either an operator with a certificate 1 or 2 and a service worker with a certificate 3 or 4 . This highlights the importance of occupation when examining labour market outcomes and possible flaws with standard specification of human capital theory as that have been highlighted by the previous literature (Shaw 1984; Shaw 1987; Heckman et al. 2003; 
Leigh 2008). Education has its largest effect on the outcomes of management and professional occupations, with a university degree increasing the probability of a professional occupation by approximately 0.3 . Lack of education has a significant influence, with people who fail to complete the final year of high school having reduced probabilities, compared to high school graduates, of being managers and professionals; they more likely to be labourers, technicians, operators or salespersons. 
Table A2: Dynasty Hysteresis Variables

\begin{tabular}{|c|c|c|c|c|}
\hline Variable & Manager & Professional & Technician & Service \\
\hline Father is manager & $0.04255^{* * *}$ & 0.00333 & -0.00391 & -0.00247 \\
\hline Father is technician & -0.00442 & -0.00646 & $0.03250^{* * *}$ & $-0.01529 * *$ \\
\hline Father is service worker & 0.0064 & -0.00917 & $0.04339 * * *$ & $-0.02812 * * *$ \\
\hline Father is clerical worker & -0.00624 & 0.00796 & $0.03398^{* * *}$ & -0.00744 \\
\hline Father is sales worker & $-0.02276 * *$ & 0.00805 & 0.00036 & 0.0135 \\
\hline Father is operator & 0.00953 & $-0.02340 *$ & 0.01632 & -0.00329 \\
\hline Father is labourer & 0.01538 & $-0.03364 * *$ & $0.02749 * *$ & $-0.01719 *$ \\
\hline Mother is manager & $0.03365 * * *$ & $-0.02359 * *$ & 0.01063 & $-0.02189 * * *$ \\
\hline Mother is technician & 0.00508 & 0.01027 & $0.03076 * *$ & $-0.03162 * * *$ \\
\hline Mother is service worker & 0.01203 & -0.01461 & -0.00069 & -0.0028 \\
\hline Mother is clerical worker & $0.02406 * *$ & -0.0139 & $0.02017 * *$ & -0.01135 \\
\hline Mother is sales worker & $0.02423 *$ & $-0.03592 * * *$ & -0.00361 & -0.00304 \\
\hline Mother i & 0.01 & 0.00917 & -0.0 & -0 . \\
\hline Mother & 0.01 & -0.01624 & 0.01224 & -0.01873 \\
\hline Father's AUSEI06 & 0.0000 & 0.00 & 0.00 & -0.0 \\
\hline \multirow{2}{*}{ Mother's AUSEI06 } & 0.00034 & 0.00006 & 0.00012 & -0.00029 \\
\hline & Clerical & Sales & Operator & Labourer \\
\hline Father is manager & $-0.02701^{* * * *}$ & $-0.01706 * * *$ & -0.00488 & 0.00945 \\
\hline Father is & -0.00342 & $89 * *$ & -0.00746 & $0.02044 * *$ \\
\hline rvice worker & 0.00263 & $-0.01416 *$ & -0.00726 & 0.00629 \\
\hline Father is clerical worker & -0.00454 & $-0.01627 * *$ & -0.00867 & 0.00122 \\
\hline Father is sales worker & -0.01591 & -0.00675 & 0.00564 & $0.01787 *$ \\
\hline Father is operator & $-0.02267 *$ & -0.00892 & 0.00052 & $0.03192 * * *$ \\
\hline Father is labourer & $-0.02807 * *$ & -0.01236 & 0.00589 & $0.04250^{* * *}$ \\
\hline Mother is manager & 0.00849 & $0.01390 *$ & $-0.02200^{* * *}$ & 0.00081 \\
\hline Mother is technician & 0.01409 & 0.01544 & $-0.02951 * * *$ & -0.01451 \\
\hline Mother is service worker & -0.00212 & $0.01964 * *$ & $-0.02168 * *$ & 0.01024 \\
\hline Mother is clerical worker & 0.01339 & 0.00647 & $-0.02071 * * *$ & $-0.01812 * *$ \\
\hline Mother is sales worker & $0.03216 * *$ & $0.02280 * *$ & $-0.02271 * *$ & -0.01392 \\
\hline Mother is operator & 0.02429 & 0.00948 & $-0.02906 * *$ & 0.01156 \\
\hline Mother is labourer & 0.01442 & 0.01821 & $-0.03247 * * *$ & 0.00897 \\
\hline Father's AUSEI06 & -0.00013 & -0.00005 & -0.00013 & 0.00012 \\
\hline Mother's AUSEI06 & 0.00001 & $0.00032 * *$ & $-0.00044 * * *$ & -0.00013 \\
\hline Legend & $* \mathrm{p}<0.1$ & $* * \mathrm{p}<0.05$ & $* * * \mathbf{p}<0.01$ & \\
\hline
\end{tabular}

Parental status also seems to have significant effects on occupational choice outcomes, albeit these effects are much smaller than those of education. Generally, social status measured by the AUSEI06 seems to be insignificant for both mother and father. However, father's AUSEI06 is significant at the ten percent level for profession while 
mother's score significantly increases the probability of being in sales and decreases the probability of being an operator.

The binary variables for parental occupation provide some support for the hypothesis of dynasty hysteresis. If the father or mother of an individual is a manager, then the probability of being a manager increases by an effect equal to about two-thirds or half of that a bachelor degree. This effect can be expected with the inheritance of business ownership within families. A similar effect is also observed for technicians for fathers and mothers and labourers for fathers. However, fathers being in service occupation seem to have a significant negative effect on this outcome. An anti-dynasty hysteresis for service occupations is an interesting finding but we will not speculate on this without further investigation, Generally, the effect t of parent binaries effects are small and range from 0.01 to 0.04 compared to own education binaries, which range from 0.01 to 0.30 .

Table A3: Demographics

\begin{tabular}{|l|l|l|l|l|}
\hline Variable & Managers & Professional & Technician & Service \\
\hline Female & $-0.06055^{* * *}$ & $-0.01816^{* * *}$ & $-0.10548^{* * *}$ & $0.02357^{* * *}$ \\
\hline Married & $0.04643^{* * *}$ & 0.00337 & $-0.02259 * * *$ & 0.00057 \\
\hline Defacto & $0.01616^{* *}$ & 0.01015 & $-0.01109^{* *}$ & -0.00515 \\
\hline Separated & 0.01167 & -0.00003 & $-0.02436^{* *}$ & 0.01472 \\
\hline Divorced & -0.00214 & $-0.01911^{* *}$ & 0.0135 & $0.01381^{*}$ \\
\hline Widow & $0.04675^{* *}$ & -0.03393 & $-0.06801^{* * *}$ & 0.02012 \\
\hline English speaking & -0.00269 & -0.00202 & 0.0034 & 0.00783 \\
\hline Non-English speaking & $-0.04858^{* * *}$ & $-0.03086^{* * *}$ & $0.02143^{* * *}$ & $0.02846 * * *$ \\
\hline & $\mathbf{C l e r i c a l}$ & Sales & Operator & Labourer \\
\hline Female & $0.20787^{* * *}$ & $0.03513^{* * *}$ & $-0.05996^{* * *}$ & $-0.02243^{* * *}$ \\
\hline Married & $0.01536 * *$ & $-0.00956^{* *}$ & $-0.01242^{* * *}$ & $-0.02119^{* * *}$ \\
\hline Defacto & 0.00541 & $-0.01116^{* * *}$ & -0.00305 & -0.00128 \\
\hline Separated & -0.01141 & 0.00304 & -0.01048 & 0.01685 \\
\hline Divorced & 0.0135 & -0.00617 & $-0.01445^{* *}$ & 0.00106 \\
\hline Widow & $0.03707^{*}$ & -0.00872 & $-0.04914^{* * *}$ & $0.05586 * *$ \\
\hline English speaking & -0.00109 & -0.00212 & $-0.00921^{* * *}$ & 0.0059 \\
\hline Non-English speaking & -0.00114 & 0.00786 & $-0.01909 * * *$ & $0.04193^{* * *}$ \\
\hline \multicolumn{1}{|c|}{ Legend } & $* \mathbf{p}<\mathbf{0 . 1}$ & $* * \mathbf{p}<\mathbf{0 . 0 5}$ & $* * * \mathbf{p}<\mathbf{0 . 0 1}$ & \\
\hline
\end{tabular}


Table A4: Sectors

\begin{tabular}{|c|c|c|c|c|}
\hline Variable & Manager & \begin{tabular}{|l|} 
Professional \\
\end{tabular} & Technician & Service \\
\hline Agriculture & 0.34722 & -0.07177 & -0.12782 & -0.00352 \\
\hline Mining & -0.09098 & 0.10451 & -0.0293 & -0.00881 \\
\hline Electricity, gas \& water & -0.10001 & 0.06537 & -0.03716 & -0.00881 \\
\hline Construction & -0.04496 & -0.06065 & 0.12923 & -0.00817 \\
\hline Wholesale & 0.01305 & 0.00242 & -0.14642 & -0.00696 \\
\hline Retail & 0.08679 & -0.08693 & -0.13492 & -0.00383 \\
\hline Accommodation \& Food & 0.18336 & -0.13243 & -0.10728 & 0.24545 \\
\hline Transport & -0.07585 & -0.00172 & -0.15748 & 0.02152 \\
\hline Telecommunication & -0.04904 & 0.1519 & 0.00094 & -0.00208 \\
\hline Finance & -0.00302 & 0.1436 & -0.17296 & -0.00782 \\
\hline Property & -0.04768 & -0.03118 & -0.18579 & 0.00934 \\
\hline Scientific & -0.07511 & 0.25999 & -0.05148 & -0.0049 \\
\hline Administrative & -0.05784 & 0.06498 & -0.11269 & 0.09221 \\
\hline Public admin and safety & -0.08688 & 0.06356 & -0.13545 & 0.2250 \\
\hline Education & -0.11488 & 0.35194 & -0.12834 & 0.19092 \\
\hline Health & -0.13825 & 0.20805 & -0.1283 & 0.29941 \\
\hline Art and recreation & -0.05489 & 0.11241 & -0.08833 & 0.23729 \\
\hline \multirow[t]{2}{*}{ Other } & -0.08742 & 0.03217 & 0.13837 & 0.11971 \\
\hline & Clerical & Sales & Operator & Labourer \\
\hline Agriculture & -0.12613 & -0.05324 & -0.05355 & 0.08881 \\
\hline Mining & 0.01378 & -0.04442 & 0.1345 & -0.0793 \\
\hline Electricity, gas \& water & 0.13545 & -0.03692 & 0.00064 & -0.01857 \\
\hline Construction & 0.04371 & -0.04827 & -0.03826 & 0.02738 \\
\hline Wholesale & 0.07128 & 0.14562 & -0.0003 & -0.07868 \\
\hline Retail & -0.10369 & 0.35954 & -0.05758 & -0.05939 \\
\hline Accommodation \& Food & -0.13382 & 0.01057 & -0.07036 & 0.0045 \\
\hline Transport & 0.18906 & \begin{tabular}{|l|l|}
-0.01977 \\
\end{tabular} & 0.11833 & -0.07409 \\
\hline Telecommunication & 0.07859 & -0.00403 & -0.06938 & -0.10689 \\
\hline Finance & 0.25837 & -0.01528 & -0.0849 & -0.11799 \\
\hline Property & 0.01599 & 0.37818 & -0.07063 & -0.06823 \\
\hline Scientific & 0.09655 & \begin{tabular}{|l|}
-0.03851 \\
\end{tabular} & -0.08373 & -0.10282 \\
\hline Administrative & -0.03433 & -0.03311 & -0.07941 & 0.16019 \\
\hline Public admin and safety & 0.12943 & -0.04504 & -0.05969 & -0.09092 \\
\hline Education & -0.08578 & -0.0571 & -0.08329 & -0.07347 \\
\hline Health & -0.05257 & -0.05661 & -0.07298 & -0.05877 \\
\hline Art and recreation & -0.06271 & -0.02069 & -0.07547 & -0.0476 \\
\hline Other & -0.05969 & -0.03112 & -0.0779 & -0.03411 \\
\hline Legend & ${ }^{*} \mathbf{p}<0.1$ & $* * \mathbf{p}<\mathbf{0 . 0 5}$ & $* * * \mathbf{p}<\mathbf{0 . 0 1}$ & \\
\hline
\end{tabular}


Table A5: Location and Date

\begin{tabular}{|l|l|l|l|l|}
\hline Variable & Managers & Professional & Technician & Service \\
\hline Victoria & -0.00588 & 0.00388 & -0.00267 & 0.00382 \\
\hline Queensland & $-0.02195^{* * *}$ & $-0.01083^{* *}$ & $0.01642^{* * *}$ & 0.00416 \\
\hline South Australia & $-0.01224^{*}$ & 0.00501 & -0.00876 & -0.00873 \\
\hline Western Australia & -0.00131 & $0.02115^{* * *}$ & 0.00266 & $-0.01131^{* *}$ \\
\hline Tasmania & $-0.03594^{* * *}$ & 0.01434 & 0.01478 & -0.00824 \\
\hline Northern territory & $0.04511^{*}$ & $-0.04489^{* *}$ & -0.00199 & -0.01939 \\
\hline Australia CT & 0.0164 & $0.02171^{*}$ & 0.01038 & $-0.03305^{* * *}$ \\
\hline 2002 & -0.00315 & -0.0055 & 0.00102 & 0.00761 \\
\hline 2003 & -0.0011 & $-0.01214^{*}$ & -0.00463 & $0.01249^{* *}$ \\
\hline 2004 & -0.00086 & -0.01066 & 0.00326 & $0.01106^{*}$ \\
\hline 2005 & $-0.01193^{*}$ & $-0.01172^{*}$ & 0.00301 & $0.01700^{* * *}$ \\
\hline 2006 & -0.00338 & $-0.01544^{* *}$ & 0.00229 & $0.01353^{* *}$ \\
\hline 2007 & $-0.01453^{* *}$ & $-0.01695^{* *}$ & $0.01226^{*}$ & $0.01638^{* * *}$ \\
\hline & $\mathbf{C l e r i c a l}$ & Sales & $\mathbf{O p e r a t o r}$ & $\mathbf{L a b o u r e r}$ \\
\hline Victoria & 0.0048 & 0.00443 & -0.00155 & $-0.00683^{*}$ \\
\hline Queensland & -0.00468 & 0.0054 & -0.00428 & $0.01577^{* * *}$ \\
\hline South Australia & 0.00485 & 0.00582 & 0.00508 & 0.00897 \\
\hline Western Australia & -0.00578 & 0.00623 & 0.00048 & $-0.01212^{* *}$ \\
\hline Tasmania & -0.00176 & 0.00933 & 0.00157 & 0.00591 \\
\hline Northern territory & $0.04549^{*}$ & -0.02062 & 0.01256 & -0.01628 \\
\hline Australia CT & 0.01457 & -0.00543 & -0.00399 & $-0.02060^{* *}$ \\
\hline 2002 & 0.01067 & -0.0051 & 0.00185 & -0.0074 \\
\hline 2003 & 0.00678 & -0.00216 & 0.00287 & -0.00211 \\
\hline 2004 & 0.00218 & 0.0011 & -0.002 & -0.00406 \\
\hline 2005 & 0.0079 & -0.00399 & -0.00029 & 0.00003 \\
\hline 2006 & 0.00752 & -0.00668 & 0.00078 & 0.00139 \\
\hline 2007 & 0.00666 & -0.00074 & 0.00265 & -0.00574 \\
\hline \multicolumn{1}{|c|}{ Legend } & $* \mathbf{p}<\mathbf{0 . 1}$ & $* * * \mathbf{p}<\mathbf{0 . 0 5}$ & $* * * \mathbf{p}<\mathbf{0 . 0 1}$ & \\
\hline & & & & \\
\hline
\end{tabular}

